\title{
Vector Development, Isolation of N ew Promoters and Enhancement of the Catalytic A ctivity of the Dsz Enzyme Complex in Rhodococcus sp. Strains
}

\author{
E. Franchi ${ }^{1}$, F. Rodriguez ${ }^{1}$, L. Serbolisca ${ }^{1}$ and F. de Ferra ${ }^{1 *}$ \\ 1 EniTecnologie SpA - Dept of Biological Sciences, Via Maritano 26 - 20079 S. Donato M ilanese (M ilano) - Italy \\ e-mail: efranchi@enitecnologie.eni.it - frodriguez@enitecnologie.eni.it - iserbolisca@enitecnologie.eni.it - fdeferra@enitecnologie.eni.it \\ * Corresponding author
}

Résumé - Développement de vecteurs, isolement de nouveaux promoteurs et augmentation de l'activité catalytique du complexe enzymatique Dsz chez des souches Rhodococcus $\mathbf{s p}$. - Le genre Rhodococcus est métaboliquement versatile, fréquemment présent dans les sols et eaux marines, il a une tolérance marquée vis-à-vis des solvants et est capable de catalyser diverses réactions de transformation des composés présents dans le pétrole brut. Parmi celles-ci, l'oxydation et le catabolisme des alcanes et des aromatiques, la désulfuration des aryl- et alkyl-sulfonates et autres composés soufrés organiques sont des caractéristiques utiles.

Dans le but de tirer un meilleur profit des performances des souches ayant des capacités de transformation des composants du pétrole (notamment la désulfuration et l'oxydation des hydrocarbures), des outils génétiques performants de modification des souches de Rhodococcus ont été développés. Des promoteurs forts et constitutifs ont été isolés et caractérisés. Des souches ont été construites, dans lesquelles la surexpression contrôlée de composants sélectionnés de la voie de désulfuration conduit à l'augmentation de l'activité de désulfuration dans des systèmes modèles.

\begin{abstract}
Vector Development, Isolation of New Promoters and Enhancement of the Catalytic Activity of the Dsz Enzyme Complex in Rhodococcus sp. Strains - Rhodococcus is a metabolically versatile genus, commonly found in soils and sea water, markedly solvent tolerant and capable of catalyzing diverse transformation reactions of compounds present in crude oil. Among these, oxidation and catabolism of alkanes and aromatics, sulfur removal from aryl-and alkyl-sulfonates and other organosulfur compounds are useful characteristics.

To better exploit the performance of strains exhibiting biotransformation of oil components (in particular desulfurization and hydrocarbon oxidation) we have developed efficient genetic tools for the engineering of Rhodococcus strains. Strong and constitutive promoters have been isolated and characterized. Strains have been constructed in which the careful overexpression of selected components of the desulfurization pathway leads to the enhancement of the sulfur removal activity in model systems.
\end{abstract}




\section{IN TRO DUCTION}

Biodesulfurization (BDS) has been proposed as a possible technology to reduce sulfur content in oil fractions in order to meet the increasingly stringent and regulated levels of sulfur in fuel [1]. The technology is based on the activity of a microbial catalyst which specifically cleaves the C-S bond in organosulfur compounds with structure similar to that of dibenzothiophene (DBT) and its alkylated derivatives $[2,3]$. Sulfur is necessary for microbial cell growth and some strains are able to utilize it from aromatic structures such as DBT, when there is no available sulfate. Most of the DBT analogs present in diesel oil are converted by the catalyst, although with decreasing efficiency on heavily substituted alkylated DBTs [3, 4]. Hydrodesulfurization (HDS) processes are also much less efficient on these compounds [5].

Depending on the process design, the level of sulfur content and the characteristics of the microorganism utilized as a catalyst, diverse levels of biodesulfurization can be obtained with natural strains, ranging from about 0.1 to $1 \mathrm{mg}$ sulfur removed/g dry cells/h, as determined using a standard DBT desulfurization assay [6]. However ten fold higher values can be obtained experimentally in optimal biocatalyst conditions [7].

In addition, process parameters, type of substrate and choice of catalyst directly influence the economics of the reaction. Recently published economic evaluation studies of the process are either favourable [8] or unfavourable [9] to BDS with respect to HDS in the 500 to $50 \mathrm{ppm}$ sulfur concentration range. Extrapolation to lower residual sulfur values is difficult to compare.

Our own preliminary evaluations (carried out in collaboration with $I F P$ ), based on a process design which includes a recycling catalyst step, and on the activity of wild-type Rhodococcus strains with performances lower but comparable to DS7, indicated the need to increase biocatalyst activity 5 to 10 fold to be competitive with HDS in the 500 to $10 \mathrm{ppm}$ range. A subsequent study, based on experimental data from a new process design which excludes any recycling of the catalyst, was performed to evaluate the main factors affecting the overall costs of a process aiming at decreasing the sulfur content of diesel oil from $100 \mathrm{ppm}(\mathrm{w} / \mathrm{w})$ down to about $15 \mathrm{ppm}(\mathrm{w} / \mathrm{w})$. From this evaluation, the level and timestability of the catalytic activity and the cost of the carbon source utilized for the growth of the catalyst were identified as the most influential parameters of the cost of a biodesulfurization process. This communication reports on the generation of new genetically modified strains constructed in order to increase the efficiency of the reaction and thus decrease the cost of the process.

\section{GENE EXPRESSION O PTIMIZATIO N TO IMPRO VE CATALYST ACTIVITY}

The $d s z A B C$ genes, located on a large plasmid in Rhodococcus sp. DS7 [10] encode the enzyme complex that catalyzes, through the $4 \mathrm{~S}$ pathway, the oxidation and C-S bond scission of organosulfur compounds. The synthesis of the Dsz complex is induced in conditions in which there is little or no available sulfate for the cells to grow and in the presence of dibenzothiophene. In the $4 \mathrm{~S}$ desulfurization pathway, DszC and A catalyze successive oxidations of the DBT molecule to DBT sulfone, DBT sulfoxide and hydroxyphenylbenzene sulfinic acid, while the last step in the desulfurization reaction is catalyzed by the product of the $d s z B$ gene [11] (Fig. 1). The activity of the 2 oxygenases DszC and DszA depends on the presence of a fourth enzymatic activity, encoded by the $d s z D$ gene which, in Rhodococcus, is separately located on the chromosome. This enzyme, which reduces the flavin mononucleotide FMN to $\mathrm{FMNH}_{2}$ in a NADH dependent way, is a limiting factor in the overall desulfurization reaction [12]

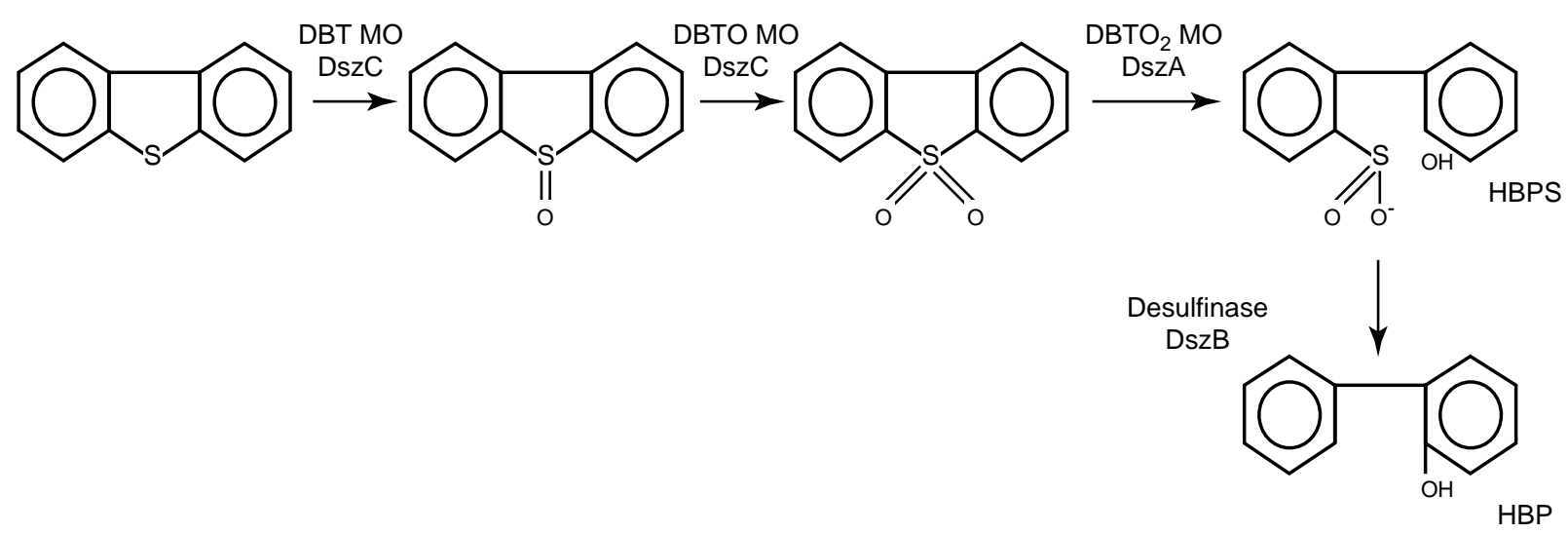

Figure 1

The 4S pathway of DBT desulfurization. 
We have used an efficient Rhodococcus gene expression system for the optimization of the entire reaction. The system is based on plasmids derived from a large Rhodococcus endogenous plasmid [10] and on the utilization of new regulatory sequences which promote an efficient expression of the genes controlled.

New, strong promoters were identified in the Rhodococcus genome by a combination of diverse promoter search techniques (to be published elsewhere). In particular, two different promoter sequences were identified and named P600 and P57, which promote high levels of transcription of exogenous genes. A promoterless copy of xylE encoding catechol 2,3 dioxygenase, was used as a reporter gene to isolate new promoters from Rhodococcus DS7, since this enzyme confers an easily detectable yellow color to cells which express its gene product when they are exposed to pyrocatechol. Figure 2 indicates the high level of synthesis and accumulation of catechol 2,3 dioxygenase in Rhodococcus DS7 cells, when $x y l E$ gene is cloned in a plasmid under the control of the P57 promoter.

Several studies using different strains reported that the activity of the DszD enzyme could be limiting in the presence of enhanced levels of expression of the other desulfurizing enzymes. In order to confirm that the same phenomenon could occour using Rhodococcus sp. DS7 and to overcome this limitation, new recombinant strains were

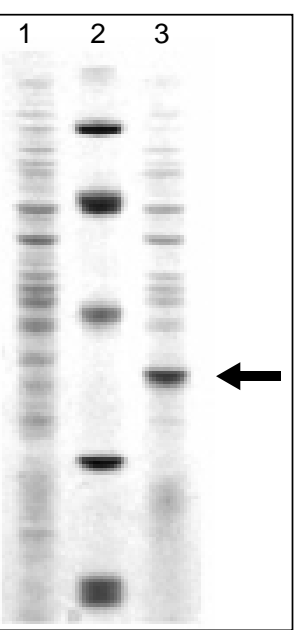

Figure 2

PAGE profile of protein extracts from 2 strains in which $x y l E$ gene expression is driven either by a weak promoter (lane 1) or by P57 (lane 3) in DS7 cells grown on minimal medium. Each lane contains the equivalent amount of protein extract corresponding to about 0.025 optical density units (A600 nm) of cells collected at mid-log phase. The arrow indicates the protein band corresponding to the product of $x y l E$. Lane 2 indicates the molecular weight markers: phosphorylase B $97.4 \mathrm{kDa}$, bovine serine albumine $66.2 \mathrm{kDa}$, ovalbumin $45.0 \mathrm{kDa}$, carbonic anhydrase $31.0 \mathrm{kDa}$, soybean trypsin inhibitor $21.5 \mathrm{kDa}$ (BioRad LMW).

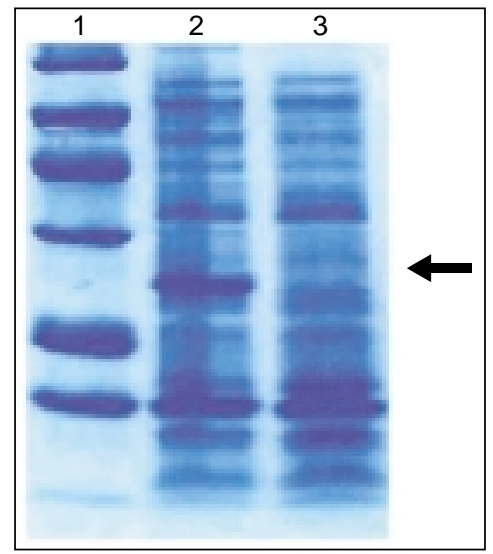

Figure 3

PAGE profile of protein extracts from strains D10 and DS7. Lane 1: molecular weight markers (BioRad LMW). Lane 2: protein pattern of the D10 strain containing $d s z D$ under the control of P57. Lane 3: wild-type Rhodococcus DS7 proteins. The arrow indicates the DszD protein band. About $20 \mathrm{mg}$ of protein were loaded.

constructed in which the $d s z D$ gene was either inserted in the chromosome under the control of the P57 promoter in a single copy (strain D10) or cloned on a plasmid under the control of its own promoter (strain D9). Figure 3 shows the protein pattern of cells harbouring the $d_{s z} D$ gene on the chromosome under the control of promoter P57. The results of NADH-dependent FMN reductase assays performed on these strains and compared to the reductase activity of the parental strain DS7 are illustrated in Figure 4. The comparison between wild type and D9 cells grown on DBT as the only source of sulfur indicates that a 2-3 fold increase in reductase activity was obtained by cloning the $d s z D$ gene on a plasmid, thus increasing its copy number/cell. In D9 cells, the expression of the $d s z D$ gene is regulated by its own promoter and reductase activity of cells grown in the presence of sulfate is inhibited to about $25 \%$ compared to the reductase activity of the same cells grown with DBT (Fig. 4b). These findings are in contrast with what was reported using a different Rhodococcus strain, where transcription from the $d s z D$ promoter is described as unaffected by the presence of sulfate [13].

After growth on DBT as a source of sulfur, D10 cells which harbour a second copy of $d s z D$ on the chromosome under the control of the P57 promoter, showed an 11-fold increase in reductase activity compared to wild type cells. In this strain, the measured reductase activity is not influenced by sulfate (Fig. 4a). These results indicate that the expression of the $d s z D$ gene is increased several folds by changing the expression system and that the gene expression regulated by the P57 promoter is not affected by the presence of sulfate during cell growth. 


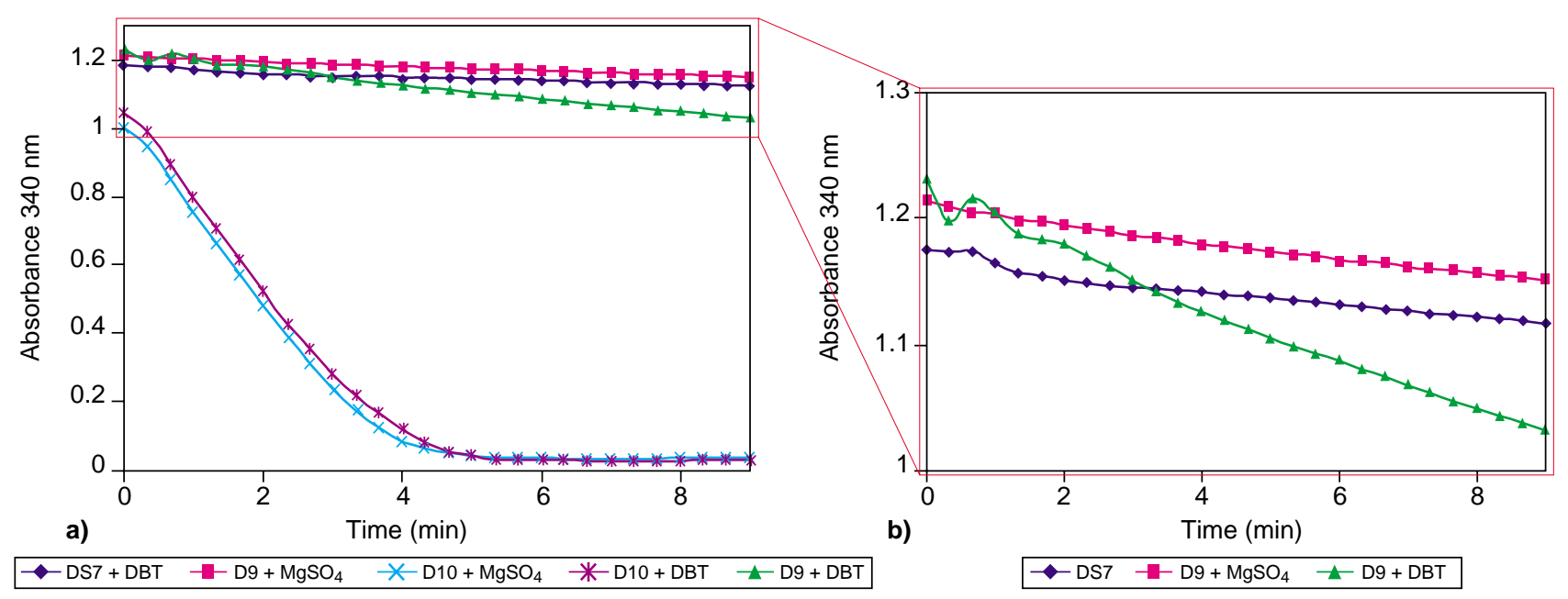

Figure 4

NADH dependent FMN reductase activity of DS7, D9 and D10 strains measured after cell growth either in the presence of sulfate or DBT as a source of sulfur.

The activity was measured as the decrease over time of absorbance $\mathrm{A}_{340}$ corresponding to conversion of added NADH to the cellular extracts of bacterial cells grown in the conditions indicated. Equal amounts of protein were used for each reaction. (a): NADH dependent FMN reductase activity of DS7 wild-type cells compared to the engineered strains D9 and D10 after cell growth either in the presence of sulfate or DBT. (b): enlargement of the upper part of (a).

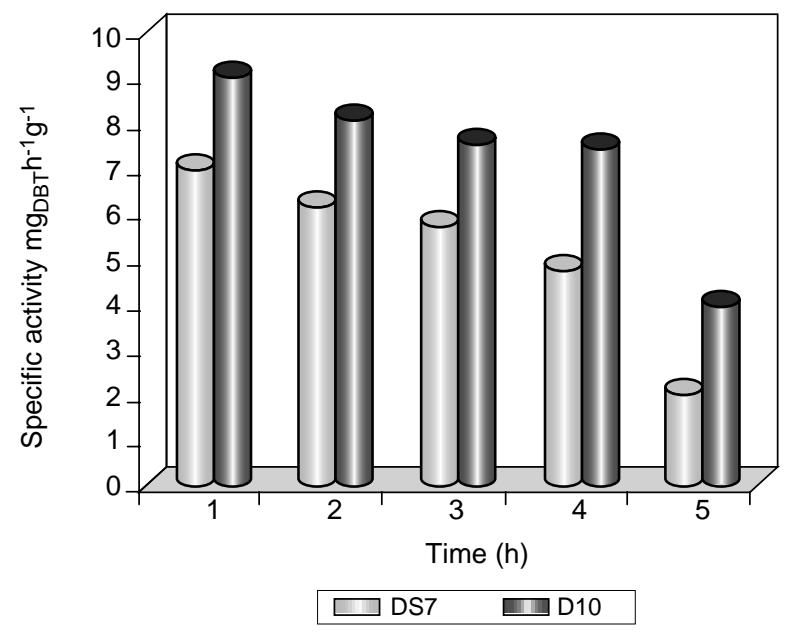

Figure 5

Desulfurization activity of DBT in 1:1 water: dodecane by strain DS7 (wild-type) compared to strain D10 overexpressing the $d s z D$ gene and transformed with a plasmid overexpressing $d s z A B C$ under the control of the P600 promoter. The assay was carried out as follows: cells grown to mid-exponential phase are concentrated to $15 \mathrm{mg}(\mathrm{dw}) / \mathrm{ml}$ in a $\mathrm{KH}_{2} \mathrm{PO}_{4} 100 \mathrm{mM} \mathrm{pH}=7$ solution, aliquoted and incubated for the time indicated, in the presence of equal volumes of dodecane containing DBT $5 \mathrm{mM}$. The products of desulphurization are analyzed by HPLC following extraction with an equal volume of ethyl acetate. Specific activity is calculated as mg DBT converted to $2-\mathrm{HBP} / \mathrm{g}$ cells (dry weight)/h. The activity values rapresent the mean values of 4 independent experiments.
The effect of the overexpression of $d s z D$ on the overall desulfurization activity was tested in DBT desulfurization assays carried out as previously described [6] and reported in the legend of Figure 5.

\subsection{Desulfurization Activity of Engineered Strains}

D10 cells, containing the $d s z A B C$ genes on a plasmid under the control of P600, a Rhodococcus promoter different from P57 and not regulated by sulfur, and wild-type DS7 cells were compared in a standard "resting cells" desulfurization assay. Figure 5 indicates the relative desulfurization activities of these strains, at different times of incubation as "resting cells" in the presence of DBT, and measured as 2-hydroxybiphenyl (2-HBP) production from DBT $(\mathrm{mg} / \mathrm{h} / \mathrm{g}$ dry cells). It can be observed that, in these conditions, D10 overexpressing the reductase gene displays a relative enhancement in desulfurization activity when compared to wild-type DS7 cells. In the same conditions, previous experiments had shown that the $d s z A B C$ overexpression under the P600 promoter resulted in a slighter increase in desulfurizing activity (data not shown). The enhancement in the rate of DBT transformation to 2-HBP is maintained in time relative to the control cells (up to a 2 fold increase relative to wild-type cells after 24-h incubation) although the activity of both strains decreased after the first 6-7 h of incubation. Moreover, we have observed that while cells from the $d s z D$ overexpressing strain D10 display a consistently higher desulfurization activity in comparison with the wild-type catalyst, the degree of variability between 

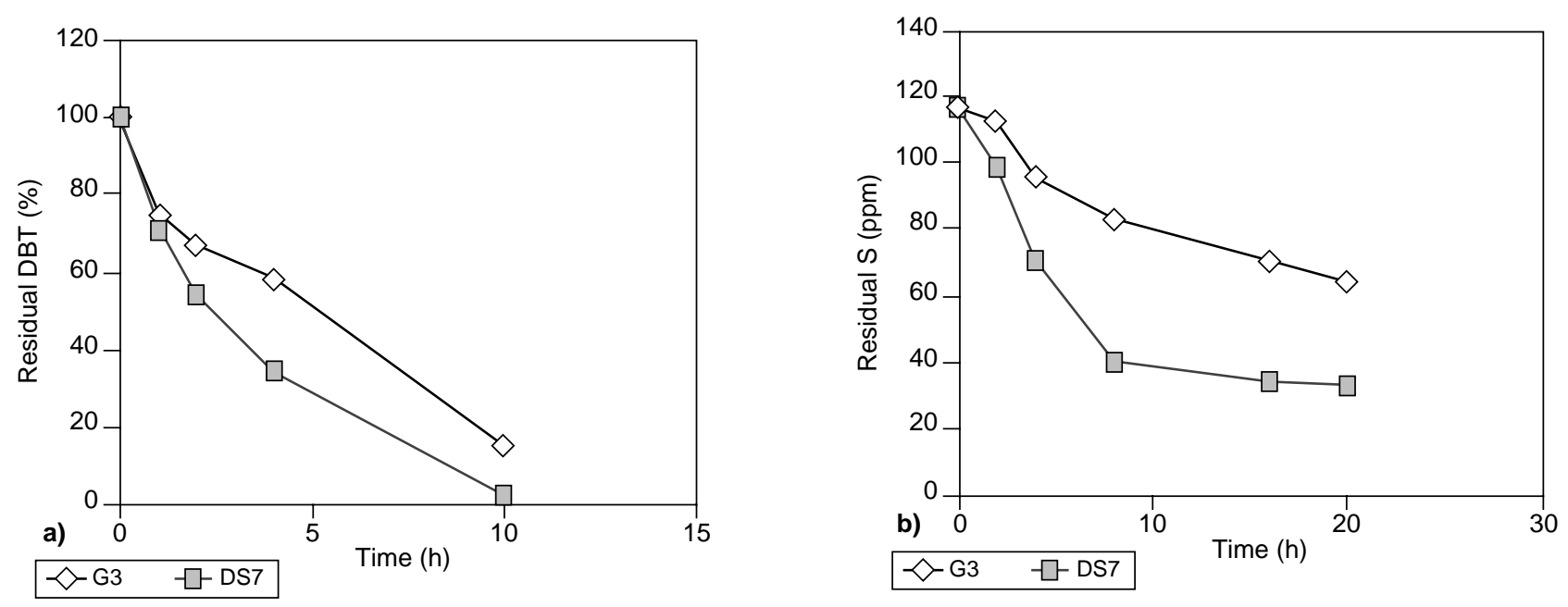

Figure 6

Desulfurization activity of strain G3 transformed with a plasmid encoding $d s z A B C$ genes compared to DS7 cells harbouring the same plasmid. The assay was carried out either in water/dodecane 1:1 containing $5 \mathrm{mM}$ DBT (a) or (b) on a reaction mixture containing 1:1 water/HDS treated diesel oil containing $116 \mathrm{ppm}$ of sulfur. Reactions were incubated for the period indicated in (a) and (b). The extent of desulfurization is expressed as percentage of initial values for (a) and as residual S ppm for (b). Organosulfur compounds present in diesel fraction were analyzed by gas chromatography equipped with a sulfur specific AED detector.

assays is increased with respect to DS7 cells. The reason for this is not clear but it is worth mentioning that $d s z D$ overexpression in Pseudomonas cells could exert a negative effect on cell growth at high levels [14].

\section{CARBON SOURCE FOR THE GROW TH OF THE CATALYST}

DS7 cells were preferentially grown on ethanol, a relatively expensive substrate for growth. We performed a screening of possible hosts for the desulfurization system, which could grow easily on other cheaper $\mathrm{C}$ sources. One of these, Rhodococcus ruber G3, was therefore selected for its growth characteristics on propane/butane and pentane. This nondesulfurizing strain has been engineered to harbour a $d s z A B C$ containing plasmid and has shown desulfurization capabilities comparable but lower than the original strain both on DBT and on a diesel oil fraction pretreated by HDS and containing $116 \mathrm{ppm}$ of sulfur (Fig. 6). It still remains to determine whether further optimization of the characteristics of the engineered version of G3 could result in a catalyst more economically attractive than the cells derived from the wild-type Rhodococcus DS7 strain.

\section{CONCLUSIONS}

The use of an efficient expression system for the $D s z$ enzymatic machinery involved in the desulfurization of DBT (and diesel oil) has brought to the construction of a strain with enhanced catalytic activity compared to the wild type DS7 Rhodococcus cells. The use of a combination of 2 strong promoters which are not regulated by sulfur to express the 4 genes involved in the $4 \mathrm{~S}$ pathway renders gene transcription completely independent from the presence of sulfur in the cell growth culture medium. However, the desulfurization activity is still about 50\% lower in these engineered strains when cultured in the presence of sulfate (data not shown), showing the existence of additional sulfur regulated factors in the control of the biodesulfurization process. We have also recently isolated strains mutated in the regulatory cycle of sulfur metabolism which upregulate the overall expression of the desulfurization pathways of Rhodococcus. Overexpression of the $d s z D$ encoded reductase has shown that an increase in DBT desulfurization activity can be obtained which, by itself could have a significant impact on the total cost of the process, once the engineered strain is optimized to stabily display the new characteristics.

On the other hand, new strains derived from Rhodococcus ruber G3 have been engineered which are able to grow on short-chain hydrocarbons, a relative inexpensive substrate readily available in a refinery process. We have indirect evidence for the superior performance of DS7 (and desulfurizing D10) cells on diesel oil fractions with respect to IGTS8 [15], G3 and other Rhodococcus strains [16, 17] expressing similar desulfurizing activity in aqueous assays. Therefore, in our opinion, DS7 could be the most favourable cellular host for any further strain engineering aimed at improving the biodesulfurization process. 


\section{REFEREN CES}

1 Lorenzetti, M. (2001) Refiners' sulfur dilemma. Oil Gas J., 99, 47, 66-76.

2 Monticello, D.J. (2000) Biodesulfurization and the upgrading of petroleum distillates. Curr. Opin. Biotechnol., 11, 540546.

3 Grossman, M.J. Lee, M.K., Prince, R.C., Minak-Bernero, V., George, G.N. and Pickering, I.J. (2001) Deep desulfurization of extensively hydrodesulfurized middle distillate oil by Rhodococcus strain ECRD-1. Appl. Environ. Microbiol., 67, 1949-1952.

4 Grossman, M.J., Lee, M.K., Prince, R.C., Garrett, K.K., George, G.N. and Pickering, I.J. (1999) Microbial desulfurization of a crude oil middle-distillate fraction: analysis of the extent of sulfur removal and the effect of removal onremaining sulfur. Appl. Environ. Microbiol., 65, 181-188.

5 Shiflett, W.K. and Krenzke, L.D. (2002) Consider new improved catalyst technologies to remove sulfur. Hydrocarb. Process., Feb.2002, 41-43.

6 D’Addario, E., Fascetti, E., Gianna, R., Serbolisca, L. and Robertiello, A. (1998) Selective microbial desulfurization of petroleum fractions. In: Proceedings World Petroleum Congresses. $15^{\text {th }}, 2,936-938$.

7 Setti, L., Farinelli, P., Di Martino, S., Frassinetti, S., Lanzarini, G., and Pifferi, P.G. (1999) Developments in destructive and non-destructive pathways for selective desulfurizations in oil-biorefining processes. Appl. Environ. Microbiol., 52, 111-117.

8 SRI Consulting (2000) Sulfur Removal from Petroleum Fuels PEP Report 230.

9 Chem Systems (2000) Biodesulfurization of Petroleum Fractions. PERP Report 98/99S7.
10 Serbolisca, L., de Ferra, F. and Margarit, I. (1999) Manipulation of the DNA coding for the desulphurizing activity in a new isolate of Arthrobacter sp. Appl. Microbiol. Biotechnol., 52, 122-126.

11 Gray, K.A., Pogrebinsky, O.S., Mrachko, G.T., Xi, L., Monticello, D.J. and Squires, C.H. (1996) Molecular mechanisms of biocatalytic desulfurization of fossil fuels. Nat. Biotechnol., 14, 1705-1709.

12 Xi, L., Squires, C.H., Monticello, D.J. and Childs, J.D. (1997) A flavin reductase stimulates DszA and DszC proteins of Rhodococcus erythropolis IGTS8 in vitro. Biochem. Biophys. Res. Commun., 230, 73-75.

13 Hirasawa, K., Ishii, Y., Kobayashi, M., Koizumi, K. and Maruhashi, K. (2001) Biosci. Biotechnol. Biochem., 65, 239246.

14 Kertesz, M.A. and Wietek, C. (2001) Desulfurization and desulfonation: applications of sulfur-controlled gene expression in bacteria. Appl. Microbiol. Biotechnol., 57, 460466.

15 Folsom, B.R., Schieche, D.R., Digrazia, P.M., Werner, J. and Palmer, S. (1999) Microbial desulfurization of alkylated dibenzothiophenes from a hydrodesulfurized middle distillate by Rhodococcus erythropolis I-19. Appl. Environ. Microbiol. 65, 4967-4972.

16 Rhee, S.K., Chang, J.H., Chang, Y.K. and Chang, H.N. (1998) Desulfurization of DBT and diesel oils by a newly isolated Gordona strain CYKS1. Appl. Environ. Microbiol., 64, 23172331.

17 Chang, J.H., Rhee, S.K., Chang, Y.K. and Chang, H.N. (1998) Desulfurization of diesel oils by a newly isolated dibenzothiophene-degrading Nocardia sp. strain CYKS2. Biotechnol. Prog., 14, 851-855.

Final manuscript received in May 2003 